\title{
Um barnafræðslu í Strandasýslu og Húnavatnssýslu 1887-1905
}

\author{
Bragi Guðmundsson \\ Abstract \\ - Um höfund \\ About the author \\ - Heimildir
}

\begin{abstract}
Rannsóknin sem hér er kynnt byggir aðallega á skýrslum sveitakennara í Strandasýslu og Húnavatnssýslu frá árunum 1887-1905. Í peim eru dýrmætar upplýsingar um ungmenni sem nutu formlegrar fræðslu á pessum tíma.
\end{abstract}

Meðal niðurstaðna er að hlutfall barna sem fengu formlega fræðslu fór smám saman hækkandi en sýslurnar tvær voru samt vel undir landsmeðaltali pegar kom að hlutfallslegri skólasókn. Barnafræðslunni var misskipt. Minnst var hún norðan Steingrímsfjarðar, á austurströnd Hrútafjarðar og í ytri hluta Vindhælishrepps á Skaga. Allmikill munur var á milli sókna og/eða hreppa. Börn og systkini húsbænda voru 71\% heildarinnar fræðsluárið 1894-1895 en fjölgaði i 78\% áratug síðar. Hlutfall pilta og stúlkna var tiltölulega jafnt og aldursbil nemenda breitt.

Heimiliskennsla var ríkjandi fræðsluform og fá börn gengu til kennslu milli bæja. Kennslustaðir voru 70 veturinn 1894-1895 og 78 áratug síðar. Nokkrir vitnisburðir eru um hvernig komið var til móts við börn fátækra. Litlar upplýsingar eru um húsakynni og aðrar ytri aðstæður. Ekkert fast skólahús var við Húnaflóa uns heimavistarskólinn á Heydalsá tók til starfa 1897 og ekkert slíkt reis næsta áratuginn. Lítið er vitað um kennsluaðferðir. Sumir kennaranna lýsa utanbókarlærdómi og yfirheyrslum en einnig voru nemendur æfðir í að skrifa eftir upplestri. Námstími var yfirleitt skammur og áhersla á að kenna ófermdum börnum skyldunámsgreinarnar fjórar: lestur, kristinfræði, skrift og reikning, að viðbættri réttritun. Eldri nemendur lásu fleira, helst náttúrufræði, landafræði og dönsku. Byggðirnar við Húnaflóa stóðu höllum fæti í próun uppfræðslu og skólamála miðað við pað sem best gerðist annars staðar. Dar réð líklega mestu dreifð búseta en einnig mögulega efnalegar aðstæður og íhaldssöm viðhorf til skólagöngu.

Efnisord: Sveitakennsla, heimiliskennsla, farkennsla, Strandasýsla, Húnavatnssýsla

\section{Inngangur}

Dessi grein er framhald af annarri sem birtist í árslok 2020 (Bragi Guðmundsson, 2020). Dar var áhersla lögð á einstaklinga sem önnuðust sveitakennslu í Strandasýslu og Húnavatnssýslu áđur en formlegri skólaskyldu var komið á 1908. Undirbúningsmenntun peirra var könnuð, aldur og hvort peir gerðu kennslu að aðalævistarfi. Grunngögnin voru fræðsluskýrslur sem ná allt aftur til 1887. Fyrstu árin voru pær óformlegar en frá og með vetrinum 1894-1895 var notað staðlað skýrsluform. Degar pað kom til skjalanna voru kennarar beðnir um samræmdar upplýsingar, sjá fyrri grein. 
Markmiðið nú er að grafast fyrir um pau börn og unglinga sem kennslunnar nutu. Um leið er reynt að varpa ljósi á menntunaraðstæður ungmenna í strjálbýlum héruðum og samanburðar leitað við annað dreifbýli eða landið allt eftir pví sem heimildir leyfa. Tvö fræðsluár eru skoðuð sérstaklega, 1894-1895 og 1904-1905. Aðeins er fjallað um nemendur peirra kennara sem sendu frá sér skólaskýrslur en Snorri Dorsteinsson, fyrrverandi fræðslustjóri, færir rök fyrir bví í bók sinni um barna- og unglingafræðslu í Mýrasýslu að kennarar hafi í reynd verið fleiri (Snorri Dorsteinsson, 2009, bls. 53). Ótalin er sú fræðsla sem var í höndum heimilisfólks á hverjum bæ.

Samanburðarrannsóknir eru fáar. Langmikilvægust er skýrsla sem Guðmundur Finnbogason vann á vegum Alpingis um fræðslu barna og unglinga veturinn 1903-1904 (Guðmundur Finnbogason, 1905) og verður oft til hennar vísað. Pá skýrslu nýtir Ólöf Garðarsdóttir, prófessor við HÍ, til pess að birta yfirlit um hlutfall ,10-14 ára barna sem voru í skóla árið 1903-1904 af sama aldurshópi í manntalinu 1901. Detta ár gengu 61\% allra íslenskra barna á aldrinum 10-14 ára í skóla“ (Ólöf Garðarsdóttir, 2010, bls. 4). Rannsókn Ólafar sýnir mikinn landshlutamun á skólasókn. Mest var hún í péttbýli við Faxaflóa og í Eyjafirði, um 90\%, en minnst í Strandasýslu, 19\%.

Ólöf miðar við 10-14 ára börn og fylgir par aldursgreindri sundurliðun á manntalinu 1901. Guðmundur Finnbogason notar einnig pann aldurshóp en tilgreinir að auki nemendur sex ára og yngri, sjö til níu ára og fimmtán ára og eldri. Í pessari rannsókn eru ungmennin við Húnaflóa aldursflokkuð eins og í manntalinu 1901. Með pví að leggja saman yngstu hópana tvo hjá Guðmundi má auðveldlega hafa pá til samanburðar við 5-9 ára börn.

Í áðurnefndri grein höfundar er umfjöllun um grunnhugtök, rætt um menntunaraðstæður almennt, rannsóknaraðferðin útskýrð og sagt frá sýslunum tveimur. Dar er meðal annars kort sem sýnir skipan prestakalla og sveitarfélaga við Húnaflóa um 1900. Dað er endurbirt hér sem Mynd 1.

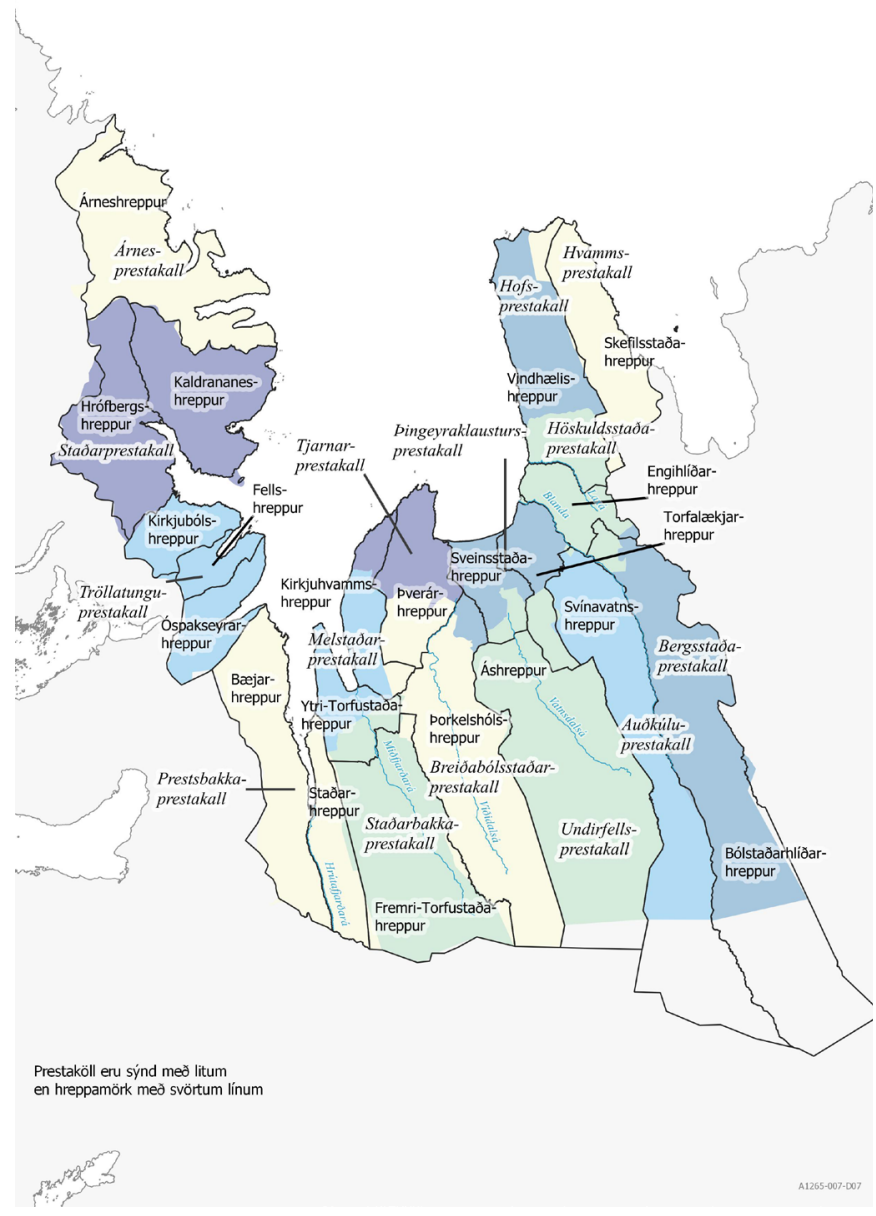

Mynd 1: Hreppar og prestaköll við Húnaflóa um 1900. Heimild að mynd: Björk Ingimundardóttir, 2019. Kortagerð: Alta ehf.

Viðfangsefnið er greint í sex hluta. Fyrst er sagt frá fjölda nemenda og aldursdreifingu peirra og athugað hvort sjá megi svæðismun hvað varðar formlega barnafræðslu. Í öðru lagi er skyggnst á bak við nöfn nemenda til að greina félagslega stöðu peirra. Í priðja lagi er pví svarað hvort kennslan var aðallega heimiliskennsla eða mikið sótt af börnum á nærliggjandi bæjum. Í peim hluta eru tekin dæmi af kennslu sveitakennara til pess að varpa ljósi á viðfangsefnið. Í fjórða lagi er rætt um aðstæður til kennslunnar og par á eftir eru nefndir stakir vitnisburðir um kennsluaðferðir. Að lokum er yfirlit um pátttöku í einstökum námsgreinum. 


\section{Heimildir og rannsóknaraðferð}

Í kennsluskýrslunum eru tilgreind öll börn sem umsækjandi kenndi á líðandi vetri, aldur peirra og námsgreinar sem hvert peirra sat. Heimili barnanna eru ekki nefnd. Sumir kennarar raða nöfnunum í stafrófsröð en aðrir fylgja (oftast) röð kennslustaða. Til pess að komast að pví hverjir nemendurnir voru eru aðallega notaðar prjár leiðir.

Fyrst var leitað í manntalsgrunni Djóðskjalasafns Íslands (www.manntal.is), aðallega manntölum frá 1890, 1901 og 1910. Grunnurinn býður leit eftir nafni einstaklings, heimili, sókn/prestakalli, sýslu, aldri og stöðu. Áreiðanleg niðurstaða fékkst í góðum meirihluta tilvika en vegna tíðra búferlaflutninga purfti oft að leita víðar. Dá var flett sóknarmannatölum á vef Djóðskjalasafnsins undir heitinu vefsjá kirkjubóka (www.skjalasafn.is). Sóknarmannatölin nefna alla sem bjuggu eða voru staddir í hverri sókn í árslok hvert ár. Í peim er oftast fylgt ákveðinni bæjaröð og auk nafna heimilisfólks er tilgreindur aldur, stétt/staða og hvort viðkomandi er fermdur, og gefin stutt umsögn um kunnáttu barna í skyldunámsgreinum. Dessi töl nýttust vel nema sóknarmannatalið fyrir Hofssókn á Skaga, sem vantar frá og með 1870, og sóknarmannatal Melstaðar í Miðfirði, sem er mjög brotakennt pau ár sem rannsóknin tekur til. Dað getur verið seinlegt að leita uppi einstaklinga en flestir fundust pegar miðað var við árslok 1894, 1895, 1904 og 1905. Loks er Íslendingabók (www.islendingabok.is) notadrjúg heimild til pess að staðfesta bæði fæðingarár og búsetu.

Orðmyndanir og greinarmerkjasetning í óprentuðum gögnum halda sér í beinum tilvitnunum en stafsetning er færð til nútímamáls. Beinar tilvitnanir í prentuð rit eru óbreyttar.

\section{Fjöldi og búseta nemenda}

Sveitarfélögin við Húnaflóa voru tuttugu, sjö í Strandasýslu og prettán í Húnavatnssýslu. Aldursskipting í hverjum hreppi liggur ekki fyrir svo heildarskipting aldurshópa í hvorri sýslu verður að duga. Ưrvinnsla úr manntalinu 1901 er í Landshagsskýrslum fyrir Ísland 1903. Áherslan er á yngstu árgangana, 0-4 ára, 5-9 ára, 10-14 ára og 15-19 ára (bls. 139-140), sjá Töflu 1.

Tafla 1. Aldursskipting í Strandasýslu og Húnavatnssýslu árið 1901. Yngstu aldurshóparnir.

\begin{tabular}{lcccc}
\hline & \multicolumn{2}{c}{ Strandasýsla } & \multicolumn{2}{c}{ Húnavatnssýsla } \\
\hline Aldur & Fjöldi & Hlutfall af heild & Fjöldi & Hlutfall af heild \\
$\mathbf{0 - 4}$ ára & 237 & $13 \%$ & 486 & $12 \%$ \\
$\mathbf{5 - 9}$ ára & 223 & $12 \%$ & 488 & $13 \%$ \\
$\mathbf{1 0 - 1 4}$ ára & 197 & $11 \%$ & 384 & $10 \%$ \\
$\mathbf{1 5 - 1 9}$ ára & 175 & $10 \%$ & 324 & $8 \%$ \\
$\mathbf{2 0}$ ára og eldri & 980 & $54 \%$ & 2209 & $57 \%$ \\
\hline Alls & $\mathbf{1 8 1 2}$ & $\mathbf{1 0 0 \%}$ & $\mathbf{3 8 9 1}$ & $\mathbf{1 0 0 \%}$ \\
\hline
\end{tabular}

Aldursdreifingin var nánast sú sama í sýslunum tveimur. Hlutfall peirra priggja aldurshópa sem aðallega sóttu fræðslu til sveitakennara, 5-19 ára, var 33\% í Strandasýslu en 31\% í Húnavatnssýslu. Samsvarandi hlutfall fyrir landið allt var 31\% (Landshagsskýrslur fyrir Ísland 1903 I, bls. 147-151). Aldursskiptingin við Húnaflóa var pví dæmigerð.

Tafla 2 sýnir fjölda peirra sem fengu formlega fræðslu í Strandasýslu og Húnavatnssýslu veturna 1894-1895 og 1904-1905. Fyrri veturinn bárust ekki stöðluð eyðublöð úr Strandasýslu og aðeins er hægt að birta samtölur pess fræðsluárs. Annar varnagli við tölurnar úr Strandasýslu sama vetur eru upplýsingar í staðfestingarbréfi séra Arnórs Árnasonar í Tröllatungu, dags. 17. apríl 1895, um kennslu Sigurgeirs Ásgeirssonar (1871-1936) í prestakallinu. Dar segir: „Ég vil leyfa mér að geta pess, að ofannefndur sveitakennari hefur haft sveitakennslu á hendi í Árnesprestakalli síðan hann hætti hér og verður hann par við kennslustörf fram yfir sumarmál“ (DÍ. Lh. Nr. XII. Ár 1894-1905). Engin skýrsla er varðveitt um pessa kennslu Sigurgeirs en hann segir sjálfur í skýrslu 
fyrir veturinn 1903-1904 að hann hafi pá kennt tíu vetur alls, par af níu í Kirkjubólshreppi og einn í Árneshreppi.

Sigurgeir Ásgeirsson stjórnaði og kenndi í nýbyggðum barna- og unglingaskóla á Heydalsá frá 1897 en sá skóli pótti ekki styrkhæfur pví hann var deildaskiptur eftir aldri. Бað verður að teljast langsótt ástæða fyrir höfnun pví margir styrkhæfir sveitakennarar kenndu fleiri eða færri ungmennum sem komin voru yfir fermingu. Um útilokunina segir í ódagsettu skjali sem ritað var á vegum stiftsyfirvalda vorið 1905: „Skóli pessi er ekki eingöngu barnaskóli, heldur einnig unglingaskóli, sem vitanlega getur eigi komið til greina við styrksútbýting pá, sem hér er um að ræða“ (DÍ. Stv. D.I. nr. 342-345).

Guðmundur Finnbogason (1905, bls. 8) telur alla nemendur Heydalsárskólans með í sinni skýrslu og pað er líka gert hér. Byggt er á skýrslum um mánađarpróf frá pví í nóvember 1904 og til vorprófs í apríl 1905 (DÍ. Sýslumaðurinn í Strandasýslu PG/3, örk 3). Í peim eru taldir samtals átján nemendur í barnadeild, ýmist fyrri eða seinni hluta vetrar, og ellefu nemendur í unglingadeild, einnig ýmist fyrri eða seinni hluta vetrar. Í skýrslunum eru aðeins nöfn nemenda en hvorki heimili né aldur. Illa gekk að átta sig á uppruna peirra sem sóttu unglingadeildina og líklega var aðeins eitt peirra úr nærsveitum skólans en nokkur úr Barðastrandarsýslu. Heildartala nemenda með búsetu í Strandasýslu er bví of há ef ætlunin er að hún sýni aðeins ungmenni paðan. Dar getur munað allt að einum tug.

Tafla 2. Nemendur við Húnaflóa fræðsluárin 1894-1895 og 1904-1905.

\begin{tabular}{lcccc}
\hline & \multicolumn{2}{c}{ Strandasýsla } & \multicolumn{2}{c}{ Húnavatnssýsla } \\
\hline Aldur & $\mathbf{1 8 9 4 - 1 8 9 5}$ & $\mathbf{1 9 0 4 - 1 9 0 5}$ & $\mathbf{1 8 9 4 - 1 8 9 5}$ & $\mathbf{1 9 0 4 - 1 9 0 5}$ \\
$\mathbf{0 - 4}$ ára & & 0 & 0 & 4 \\
$\mathbf{5 - 9}$ ára & & 21 & 81 & 103 \\
$\mathbf{1 0 - 1 4}$ ára & & 36 & 128 & 155 \\
$\mathbf{1 5 - 1 9}$ ára & & 11 & 40 & 36 \\
$\mathbf{2 0}$ ára og eldri & 86 & 3 & 7 & 10 \\
Óvíst & $\mathbf{8 6}$ & 7 & 0 & 0 \\
\hline Alls & & $\mathbf{7 8}$ & $\mathbf{2 5 6}$ & $\mathbf{3 0 8}$ \\
\hline
\end{tabular}

Einn nemandi er tvítalinn í skýrslu kennara. Dað er frávik pví pótt nemendur fengju kennslu hjá sama kennara á fleiri en einum bæ eru nöfn peirra jafnan talin einu sinni í hverri skýrslu. Fræðsluárið 1894-1895 fengu fimmtán nemendur kennslu hjá sama kennara á fleiri en einum bæ í Húnavatnssýslu og tíu árum síðar hafði peim fjölgað í 37. Engin dæmi eru um petta í Strandasýslu umrædd ár.

Nokkur dæmi eru um að nemendur hafi notið kennslu tveggja kennara sama veturinn og séu í tveimur skólaskýrslum. Hægt er að lækka heildartölu nemenda sem pessu nemur en pað fækkar ekki nemendum kennaranna sem allir telja réttilega fram. Niðurstaða höfundar er að fara eftir uppgefinni nemendatölu peirra pótt einstaklingarnir séu heldur færri en skýrslurnar nefna. Sams konar tvítalningar eru örugglega í tölum um nemendur sveitakennara í skýrslu Guðmundar Finnbogasonar.

Hægt er að bera fjölda ungmenna sem fengu formlega tilsögn hjá sveitakennurum saman við aldursdreifinguna 1901. Niðurstaðan er sýnd í Töflu 3. Dótt aldur nemenda á Ströndum 18941895 komi ekki fram má fullyrða út frá námsgreinunum sem kenndar voru að peir falli flestir eða allir innan aldurshópanna priggja. 
Tafla 3. Nemendur hjá sveitakennurum við Húnaflóa. Hlutfall af heildarfjölda sömu aldurshópa árið 1901.

\begin{tabular}{ccccc}
\hline & \multicolumn{2}{c}{ Strandasýsla } & \multicolumn{2}{c}{ Húnavatnssýsla } \\
Aldur & Hlutfall & Hlutfall & Hlutfall & Hlutfall \\
nemenda & $\mathbf{1 8 9 4 - 1 8 9 5}$ & $\mathbf{1 9 0 4 - 1 9 0 5}$ & $\mathbf{1 8 9 4 - 1 8 9 5}$ & $\mathbf{1 9 0 4 - 1 9 0 5}$ \\
\hline $\mathbf{5 - 9}$ ára & & $9 \%$ & $17 \%$ & $21 \%$ \\
$\mathbf{1 0 - 1 4}$ ára & $15 \%$ & $18 \%$ & $33 \%$ & $40 \%$ \\
$\mathbf{1 5 - 1 9}$ ára & & $6 \%$ & $12 \%$ & $11 \%$ \\
\hline
\end{tabular}

Af pessum tölum má álykta að í Húnavatnssýslu hafi fræðsla sveitakennara nád smám saman til stækkandi hóps barna undir fermingaraldri en erfiðara er að meta stöðuna á Ströndum.

Hátt hlutfall yngstu barnanna er athyglisvert og pað skýrir Guðmundur Finnbogason pannig að í föstum skólum hafi fræðslan að langmestu leyti afmarkast við 7/8-14 ára börn. Í farskólum til sveita var annar bragur á:

Dar sem haldinn er farkennari, er reynt að færa sér kenslu hans í nyt eftir föngum. Fermdir unglingar fá pá að njóta tilsagnar um leið, og kennarinn er látinn hafa pau börnin með til kenslu, sem eru að byrja að læra lestur. Dað eru jafnvel nokkur priggja ára gömul börn talin sem nemendur á skýrslunum, svo nógu snemma er nú byrjað! (Guðmundur Finnbogason, 1905, bls. 40).

Forvitnilegt er hvort sjáanlegur er svæðismunur hvað varðar formlega fræðslu. Byrjum á Húnavatnssýslu. Par nutu mjög fá börn formlegrar fræðslu á austurströnd Hrútafjarðar og í Hofsprestakalli (norðan Hallár) á Skaga. Hér verða tvö önnur svæði tekin til sérstakrar skoðunar. Fyrir valinu verður annars vegar Staðarbakkaprestakall, sem náði yfir innri hluta Miðfjarðar, ystu bæir Reynhólar, Staðarbakki og Bergsstaðir. Mestallt prestakallið var í Fremri-Torfustaðahreppi og innan pess voru tvær sóknir, Staðarbakkasókn og Efra-Núpssókn. Hins vegar er Höskuldsstaðaprestakall, sem hafði norðurmörk við Hallá. Daðan teygði pað sig yfir Norðurárdal og Laxárdal að Litla-Vatnsskarði sem fremsta bæ. Sunnan og vestan Langadalsfjalla tók prestakallið til Refasveitar norðan Blönduóss og teygði sig paðan fram Langadal að Auðólfsstöðum. Í prestakallinu voru tvær sóknir, Höskuldsstaðasókn og Holtastaðasókn. Fræðsluskýrslur eru greinargóðar úr báðum prestaköllunum og sóknarmannatöl sömuleiðis.

Aldurshóparnir 5-9 ára og 10-14 ára eru skoðaðir af peirri ástæðu að yfir 80\% barna sem einhverja fræðslu fengu hjá sveitakennurum voru á peim aldri.

Niðurstöður eru settar fram í tveimur töflum og er peim skipt eftir sóknum. Dað er gert til pess að sýna að pótt börnin séu ekki mörg er auðsjáanlegur munur, bæði á milli prestakallanna en einnig sókna innan peirra, sjá Töflur 4 og 5. 
Tafla 4. Staðarbakkaprestakall. Heildarfjöldi barna og hlutfall skráđra nemenda fræðsluárin 1894-1895 og 1904-1905.

\begin{tabular}{lcccccc}
\hline & \multicolumn{3}{c}{$\mathbf{1 8 9 4 - 1 8 9 5}$} & \multicolumn{3}{c}{$\mathbf{1 9 0 4 - 1 9 0 5}$} \\
& $\begin{array}{c}\text { Fjöldi } \\
\text { barna }\end{array}$ & $\begin{array}{c}\text { Fjöldi } \\
\text { nemenda }\end{array}$ & $\begin{array}{c}\text { Hlutfall } \\
\text { nemenda }\end{array}$ & $\begin{array}{c}\text { Fjöldi } \\
\text { barna }\end{array}$ & $\begin{array}{c}\text { Fjöldi } \\
\text { nemenda }\end{array}$ & $\begin{array}{c}\text { Hlutfall } \\
\text { nemenda }\end{array}$ \\
\hline Staðarbakkasókn & & & & & & \\
4-9 ára & 18 & 1 & $6 \%$ & 28 & 11 & $39 \%$ \\
$\mathbf{1 0 - 1 4}$ ára & 19 & 4 & $21 \%$ & 27 & 14 & $52 \%$ \\
Samtals & $\mathbf{3 7}$ & $\mathbf{5}$ & $\mathbf{1 4 \%}$ & $\mathbf{5 5}$ & $\mathbf{2 5}$ & $\mathbf{4 5 \%}$ \\
& & & & & & \\
Efra-Núpssókn & 13 & 2 & $15 \%$ & 23 & 9 & $39 \%$ \\
4-9 ára & 18 & 5 & $28 \%$ & 21 & 14 & $67 \%$ \\
$\mathbf{1 0 - 1 4}$ ára & $\mathbf{3 1}$ & $\mathbf{7}$ & $\mathbf{2 3} \%$ & $\mathbf{4 4}$ & $\mathbf{2 3}$ & $\mathbf{5 2 \%}$ \\
Samtals & & & & & & \\
& & & & & & \\
Staðarbakkaprestakall alls & & 31 & $10 \%$ & 51 & 20 & $39 \%$ \\
$\mathbf{4 - 9}$ ára & 37 & 9 & $24 \%$ & 48 & 28 & $58 \%$ \\
$\mathbf{1 0 - 1 4}$ ára & $\mathbf{6 8}$ & $\mathbf{1 2}$ & $\mathbf{1 8} \%$ & $\mathbf{9 9}$ & $\mathbf{4 8}$ & $\mathbf{4 8 \%}$ \\
\hline Samtals & & & & &
\end{tabular}

Tafla 5. Höskuldsstaðaprestakall. Heildarfjöldi barna og hlutfall skráðra nemenda fræðsluárin 1894-1895 og 1904-1905.

\begin{tabular}{|c|c|c|c|c|c|c|}
\hline & \multicolumn{3}{|c|}{$1894-1895$} & \multicolumn{3}{|c|}{$1904-1905$} \\
\hline & $\begin{array}{l}\text { Fjöldi } \\
\text { barna }\end{array}$ & $\begin{array}{c}\text { Fjöldi } \\
\text { nemenda }\end{array}$ & $\begin{array}{c}\text { Hlutfall } \\
\text { nemenda }\end{array}$ & $\begin{array}{l}\text { Fjöldi } \\
\text { barna }\end{array}$ & $\begin{array}{c}\text { Fjöldi } \\
\text { nemenda }\end{array}$ & $\begin{array}{c}\text { Hlutfall } \\
\text { nemenda }\end{array}$ \\
\hline \multicolumn{7}{|l|}{ Höskuldsstaðasókn } \\
\hline 4-9 ára & 30 & 9 & $30 \%$ & 44 & 13 & $30 \%$ \\
\hline 10-14 ára & 22 & 7 & $32 \%$ & 40 & 16 & $40 \%$ \\
\hline Samtals & 52 & 16 & $31 \%$ & 84 & 29 & $35 \%$ \\
\hline \multicolumn{7}{|l|}{ Holtastaðasókn } \\
\hline 4-9 ára & 26 & 9 & $35 \%$ & 24 & 11 & $46 \%$ \\
\hline 10-14 ára & 15 & 14 & $93 \%$ & 22 & 18 & $82 \%$ \\
\hline Samtals & 41 & 23 & $56 \%$ & 46 & 29 & $63 \%$ \\
\hline \multicolumn{7}{|l|}{ Höskuldsstaðaprestakall alls } \\
\hline 4-9 ára & 56 & 18 & $32 \%$ & 68 & 24 & $35 \%$ \\
\hline 10-14 ára & 37 & 21 & $57 \%$ & 62 & 34 & $55 \%$ \\
\hline Samtals & 93 & 39 & $42 \%$ & 130 & 58 & $45 \%$ \\
\hline
\end{tabular}


Skipulögð barnafræðsla var meiri í Höskuldsstaðaprestakalli en í Miðfirði fyrir aldamótin 1900. Áratug síðar hafði dæmið jafnast. Pá var formleg fræðsla fyrr á ferðinni í Holtastaðasókn (Langidalur og miðhluti Laxárdals) en annars staðar. Par fengu langflest 10-14 ára börn fræðslu hjá barnakennara pegar við lok nítjándu aldar. Til samanburðar má nefna að veturinn 1903-1904 fengu 42\% allra 7-14 ára barna utan kaupstaðanna fjögurra einhverja fræðslu hjá sveitakennurum (Guðmundur Finnbogason, 1905, bls. 14).

Í Strandasýslu voru öll börnin sem vitað er með vissu að fengu formlega kennslu veturinn 1894-1895 úr Kaldrananeshreppi (18), Kirkjubólshreppi (9) og Bæjarhreppi (39), að ógleymdum óskráðum nemendum Sigurgeirs Ásgeirssonar í Árneshreppi. Seinna fræðsluárið, 1904-1905, er hægt að skoða Bæjarhrepp með sams konar hætti og húnvetnsku sóknirnar. Hann var allur innan Prestsbakkaprestakalls, syðst í sýslunni. Nyrsti bær var Skálholtsvík en Gilhagi syðstur. Niðurstöður eru í Töflu 6. Par sést að skipulögð barnafræðsla í Bæjarhreppi var ríflega á pari við húnvetnsku prestaköllin tvö pað fræðsluár sem skoðað er.

Tafla 6. Bæjarhreppur. Heildarfjöldi barna og hlutfall skráđra nemenda fræðsluárið 19041905.

\begin{tabular}{|c|c|c|c|}
\hline & \multicolumn{3}{|c|}{ 1904-1905 } \\
\hline & Fjöldi barna & Fjöldi nemenda & Hlutfall nemenda \\
\hline \multicolumn{4}{|c|}{ Bæjarhreppur } \\
\hline 4-9 ára & 44 & 20 & $45 \%$ \\
\hline 10-14 ára & 34 & 21 & $62 \%$ \\
\hline Samtals & 78 & 41 & $53 \%$ \\
\hline
\end{tabular}

Enn er rétt að staldra við skólann á Heydalsá. Vitað er um aldur sextán nemenda í barnadeildinni pennan vetur. Af peim var eitt níu ára, tólf voru 10-14 ára og prjú 15-19 ára. Tíu nemendur áttu heima í Kirkjubólshreppi, sveitarfélagi skólans. Níu peirra voru 10-14 ára en alls voru 33 börn í hreppnum á peim aldri pennan vetur og skólasóknin pví 27\%. Guðmundur Finnbogason (1905, bls. 8) segir alla nemendur Heydalsárskólans úr Kirkjubólshreppi en pað fær ekki staðist. 


\section{Félagsleg staða}

Sóknarmannatöl tilgreina samfélagsstöðu hvers heimilismanns. Óvíst er að sóknarprestar hafi allir skilið hugtök á nákvæmlega sama veg en að pví slepptu er félagsleg staða nemenda sýnd í Töflu 7. Fjöldi peirra sem tókst að afla fullnægjandi upplýsinga um er í neðstu línu.

Tafla 7. Félagsleg staða nemenda á heimili eftir sýslum og fræðsluárum.

\begin{tabular}{|c|c|c|c|c|c|c|}
\hline \multirow[b]{2}{*}{ Staða á heimili } & \multicolumn{2}{|c|}{ Strandasýsla } & \multicolumn{2}{|c|}{ Húnavatnssýsla } & \multicolumn{2}{|c|}{ Samtals } \\
\hline & $1894-1895$ & $1904-1905$ & 1894-1895 & 1904-1905 & 1894-1895 & 1904-1905 \\
\hline Barn húsbænda & 17 & 42 & 174 & 240 & 191 & 282 \\
\hline $\begin{array}{l}\text { Systkini hús- } \\
\text { bænda }\end{array}$ & & & & 4 & & 4 \\
\hline Fósturbarn & 2 & 4 & 14 & 8 & 16 & 12 \\
\hline Tökubarn & 2 & & 20 & 28 & 22 & 28 \\
\hline Niðursetningur & 1 & 1 & 14 & 6 & 15 & 7 \\
\hline Léttastúlka & & & 1 & 1 & 1 & 1 \\
\hline Léttadrengur & 1 & 1 & 1 & 1 & 2 & 2 \\
\hline Vinnudrengur & & & & 1 & & 1 \\
\hline Smali & & 1 & 1 & & 1 & 1 \\
\hline Vinnukona & & 2 & 4 & 2 & 4 & 4 \\
\hline Barn vinnukonu & 2 & & 2 & 2 & 4 & 2 \\
\hline Vinnumaður & & & 3 & 1 & 3 & 1 \\
\hline Barn vinnumanns & & & 1 & 1 & 1 & 1 \\
\hline Barn vinnuhjóna & & & 1 & 2 & 1 & 2 \\
\hline Barn húshjóna & & 7 & 4 & 4 & 4 & 11 \\
\hline Barn húskonu & 1 & 3 & 2 & 1 & 3 & 4 \\
\hline Barn lausakonu & & & & 2 & & 2 \\
\hline Barn lausamanns & & 1 & & & & 1 \\
\hline Alls & 26 & 62 & 242 & 304 & 268 & 366 \\
\hline
\end{tabular}

Til pess að skerpa heildarmyndina er rétt að fækka flokkunum og reikna út hlutfallslega stærð peirra. Hér er nemendunum skipt í sex hópa, sjá Töflu 8, og heildarniðurstaðan birt óháð sýslufélögum.

- Börn og systkini húsbænda. Flest voru börn hjóna en nokkur höfðu misst annað foreldrið.

- Fósturbörn voru nálægt fjölskyldutengslum við húsbændur. Mörg voru líklega börn frændfólks sem gat ekki séð fyrir peim eða heimilin verið leyst upp. Hér eru einnig höfð tökubörn pví pótt pau ælust upp hjá vandalausum var ekki greidd meðgjöf.

- Niðursetningar skipa priðja hópinn. Pau heimili sem tóku pessi börn fengu meðgjöf frá viðkomandi hreppsfélagi.

- Börn vinnufólks, lausafólks og húsfólks eru talin saman pví skilin á milli voru frekar óglögg. Vinnufólk er óparft að skilgreina en húsfólk leigði gjarnan afmarkað húsrými fyrir sig og nokkrar skepnur. Til lausafólks töldust einstaklingar sem ekki voru vistráðnir til ársins heldur réðu atvinnu sinni frá einum tíma til annars.

- Hugtökin léttastúlka, léttadrengur, vinnudrengur og smali eru skyld og vísa til pess að viðkomandi voru utanaðkomandi, komin yfir fermingu og án meðgjafar.

- Vinnufólkið var ungt að árum en komið nokkuð yfir fermingu. 
Tafla 8. Félagsleg staða nemenda á heimili, hlutfallstölur.

\begin{tabular}{lcc}
\hline Félagsleg staða á heimili & $\mathbf{1 8 9 4 - 1 8 9 5}$ & $\mathbf{1 9 0 4 - 1 9 0 5}$ \\
\hline Barn og systkini húsbænda & $71 \%$ & $78 \%$ \\
Fósturbarn og tökubarn & $14 \%$ & $11 \%$ \\
Niðursetningur & $6 \%$ & $2 \%$ \\
Barn vinnufólks, lausafólks og húsfólks & $5 \%$ & $6 \%$ \\
Léttastúlka, léttadrengur, vinnudrengur og smali & $1 \%$ & $1,5 \%$ \\
Vinnufólk & $3 \%$ & $1,5 \%$ \\
\hline Alls & $\mathbf{1 0 0} \%$ & $\mathbf{1 0 0} \%$ \\
\hline
\end{tabular}

Helst vekur athygli hversu mörg börn áttu kost á formlegri fræðslu pótt pau væru ekki á framfæri foreldra sinna. Engar rannsóknir eru til að bera sig saman við en í manntalinu 1901 voru sveitarómagar 44 í Strandasýslu og 72 í Húnavatnssýslu. Á landinu öllu voru peir 3\% heildarmannfjöldans og sérstaklega er tekið fram að peir hafi aðeins verið 1,8\% (voru reyndar 1,9\%) 1 Húnavatnssýslu, sem var næstlægsta hlutfallið (Landshagsskýrslur fyrir Ísland 1903 I, bls. 188-189, 221-222). Sveitarómagar voru flestir börn sem fengu oft aðra félagslega stöðu eftir fermingu og töldust vinna fyrir sér.

\section{Heimiliskennsla og farkennsla}

Loftur Guttormsson, prófessor við HÍ, segir mörk heimiliskennslu og farkennslu hafa verið óglögg á nítjándu öld og að helst hafi efnafólk getað ráðið heimiliskennara (2008c, bls. 62-63). Skýrslur sveitakennara veita drjúgar upplýsingar um fyrra atriðið pótt ekki sé alltaf skýrt hvaða nemendum var kennt á hverjum stað. Nú skulu tekin nokkur dæmi um leið og reynt er að veita fáorðar upplýsingar um hvern kennara sem nefndur er.

Jón „eldri“ Jónsson (1850-1959), bóndi á Drangsnesi, kenndi átján nemendum á fjórum bæjum veturinn 1894-1895, premur til sex í senn, tvær til fjórar vikur á hverjum stað, samtals prettán vikur. Einn fékk kennslu á tveimur bæjum. Ellefu fengu kennslu heima hjá sér en sjö voru af nágrannabæjum (DÍ. Lh. Nr. XII. Ár 1894-1905). Ekki er vitað hvort peim var komið fyrir á kennslustað eða hvort peir gengu á milli. Fáum vetrum fyrr fékk Jón pá umsögn hjá séra Ísleifi Einarssyni á Stað að hann hefði ,góð áhrif á hugi barnanna, enda er pess að geta, eins og eg áđur hef skýrt frá, er [hann] söngfróđur maður, og getur pað, pegar sálmasöngur er hafður við kennsluna, með öðru fleiru, vakið og glætt tilfinning barnanna fyrir hinu guðlega og siðferðislega“" (DÍ. Lh. N.J. Ár 1891).

Sigurjón Jónsson (1865-1931) á Kollsá í Bæjarhreppi var árið 1903-1904 sagður hafa sextán ára kennslureynslu og menntun hans heimakennsla. Sigurjón kenndi 24 nemendum veturinn 19041905 á premur sveitabæjum og á Borðeyri, fjórar til fimm vikur á hverjum stað, samtals nítján vikur. Fimmtán pessara var kennt heima hjá sér og sjö Borðeyringum var kennt par á staðnum. Systkinahópar voru nokkrir og aðeins tveir komu til kennslu af nágrannabæjum (BÍ. Lh. Nr. XII. Ár 1894-1905).

Ingibjörg Finnsdóttir (1880-1972) frá Kjörseyri í Bæjarhreppi kenndi lengi. Nemendur hennar voru fjórtán veturinn 1904-1905 og kennslustaðir voru prír. Einum nemanda var kennt á Kjörseyri í sex vikur, sex á Valdasteinsstöðum í jafnlangan tíma og sjö í Fögrubrekku í tólf vikur. Ellefu pessara nemenda var örugglega kennt heima hjá sér, mögulega tólf. Í Fögrubrekku kenndi Ingibjörg premur 5-9 ára dæetrum húsbænda, ellefu ára fósturdóttur peirra og sextán ára vinnukonu. Óvíst er hvaðan einn nemendanna í Fögrubrekku var. Á Valdasteinsstöðum voru fjórir 9-13 ára synir húsbænda uppistaðan í nemendahópnum (DÍ. Lh. Nr. XII. Ár 1894-1905). 
Margrét Helga Eiríksdóttir (1877-1967) á Sveðjustöðum á Hrútafjarðarhálsi kenndi lengi. Nemendur hennar voru 29 frá tíu heimilum veturinn 1904-1905. Kennslustaðir voru sex og kennt var tvær til sjö vikur á hverjum bæ, samtals 26 vikur. Að minnsta kosti 23 var kennt heima hjá sér en hin börnin voru af nágrannabæjum (DÍ. Lh. Nr. XIII. Ár 1894-1905). Engin leið er að vita hvort pau gengu til og frá kennslustað dag hvern.

Eggert Helgason (1830-1910) í Helguhvammi á Vatnsnesi kenndi í mörg ár en yfirleitt skamman tíma á hverjum bæ. Hann segir til dæmis í skýrslu 28. janúar 1891: „Heima gjöri ég ráð fyrir að verða mánaðartíma og að pá komi börn til mín eftir sem kringumstæður leyfa. Á Hlíð, hvar 4 börn eru á náms aldri, og á Syðri-Völlum hvar og eru 4 börn, hefi ég staldrað við 1-2 daga í senn á ferðum mínum í pví skyni að styðja nám barnanna lítið eitt, og pað mun ég og framvegis gjöra eftir pví sem ég get" (DÍ. Lh. N.J. Ár 1891). Eggert kenndi 41 barni á átta bæjum veturinn 18941895 og var á hverjum stad 1-31/2 viku, samtals nítján vikur. Um tuttugu pessara barna áttu heima á einhverjum peirra bæja sem Eggert kenndi á en hin tuttugu annars staðar, flest á nágrannabæjum. Samkvæmt skólaskýrslu voru heimili barnanna samtals 22 (DÍ. Lh. Nr. XIII. Ár 1894-1905). Engin leið er að vita hversu mörg gengu á milli bæja eða var komið fyrir á kennslustað. Veturinn 1904-1905 kenndi Eggert sextán börnum á premur bæjum. Peim var öllum kennt heima hjá sér nema einu sem purfti að ganga um 600 metra til og frá kennslu. Geta má pess að meðal nemenda voru átta 7-14 ára systkini, eitt á hverju aldursári, til heimilis á Bessastöðum á Heggstaðanesi. Um pað heimili og annað til segir Eggert í skólaskýrslu að ,pessum og peim líkum heimilum mundi „skólaskyldan“ ekki pægileg verða“ (DÍ. Lh. Nr. XIV. Ár 1894-1905). - Yfirvofandi sampykkt nýrra fræðslulaga var honum greinilega í huga.

Sigríður Friðriksdóttir (1877-1944) frá Bakkakoti í Vỉðidal var dæmigerður heimiliskennari. Hún kenndi 23 börnum í Víðidal veturinn 1904-1905, kennslustaðir voru sex og á fimm peirra kenndi hún einvörðungu premur til fimm systkinum. Aldursbilið var mest tíu ár hjá systkinum í Melrakkadal en aldursspönnin í heild var ellefu ár, p.e. fjögurra til fimmtán ára. Í Víðidalstungu var ein stúlka utanaðkomandi, frá Valdarási. Henni hefur væntanlega verið komið fyrir bær vikur sem kennslan stóð pví alllangt er á milli, um 3,7 km í beinni loftlínu. Sigríður var prjár til fimm vikur á hverjum stað og kenndi samtals í 26 vikur (DÍ. Lh. Nr. XIII. Ár 1894-1905).

Halldór Sigurður Halldórsson (1866-1929) á Móbergi í Langadal kenndi lengi. Um hann segir séra Eggert Ó. Brím á Höskuldsstöđum í meðmælabréfi, dags. 18. janúar 1888, að Halldór sé „,siðlátur piltur, allvel að sér, lipur að segja til, og hafði pegar á 17. og 18. ári lag á að ávinna sér elsku og virðing barna peirra, er hann veitti tilsögn. Starf hans hefir og haft góðan árangur, og börn á peim heimilum, er hann hefir verið lengra eða skemmra tíma, hafa sýnilega tekið góðum framförum, meðan pau nutu tilsagnar hans við“ (DÍ. N.J. 1888-1892. Ár 1889). Veturinn 1894-1895 hafði Halldór 29 nemendur frá prettán heimilum og kenndi peim á sjö bæjum, tvær til átta vikur á hverjum stað, samtals 28 vikur. Í pað minnsta átján var kennt heima hjá sér en hinir voru af nágrannabæjum sem allir voru í göngufæri við kennslustaðina (DÍ. Lh. Nr. XIII. Ár 1894-1905).

Björn Árnason (1870-1932) frá Pverá í Hallárdal kenndi allmarga vetur. Almanaksárið 1893 kenndi hann 26 ungmennum á aldrinum 6-19 ára í Engihlíðar- og Vindhælishreppum. Systkinahópar voru sex en heimili nemenda sjö. Öllum nema premur var kennt heima hjá sér. Hin gengu daglega til og frá heimilum sínum, öll stutta leið. Eitt purfti pó að fara yfir Laxá til kennslunnar (DÎ. Lh. Nr. XIII. Ár 1894-1905). Björn var vel látinn og séra Jón Pálsson á Höskuldsstöđum segir í meðmælabréfi sínu, dags. 18. febrúar 1894, að hann „,é mjög laginn og lipur til að kenna börnum, og að börn pau, er notið hafa tilsagnar hans, hafi tekið góðum og miklum framförum“ (DÍ. Lh. Nr. XIII. Ár 1894-1905).

Frímann Finnsson (1872-1937) á Jaðri á Skagaströnd ,starfaði að kennslu meira eða minna flesta eða alla vetur frá 1905 fram á síðustu ár. Kenndi piltum undir sjómannaskóla. Starfaði annars mest að sjómennsku, skipstjóri um skeið“ (Ólafur P. Kristjánsson og Sigrún Harðardóttir, 1985- 
1988, 1, bls. 147-148). Í skólaskýrslu Frímanns vorið 1905 eru nöfn 27 nemenda frá átta bæjum sem kennt var á fimm stöðum, tvær til átta vikur í senn, samtals 24 vikur. Uppistaðan á hverjum bæ voru systkini, flest á Balaskarði, sjö talsins á aldrinum sex til sautján ára. Samtals var 23 börnum kennt heima hjá sér en fjögur áttu heima í næsta nágrenni (BÍ. Lh. Nr. XIII. Ár 1894-1905).

Yfirlit um fjölda og kynskiptingu nemenda, samanlagða tölu heimila peirra, fjölda kennslustaða og kennara er í Töflu 9. Nokkrir annmarkar eru á að fullgera upplýsingarnar um Strandasýslu af ástæðum sem pegar hafa verið tilgreindar. Skólinn á Heydalsá er inni í tölunum 1899-1900 svo meðalfjöldi kennslustaða á kennara í sýslunni verður villandi. Annar peirra (Sigurgeir Ásgeirsson) kenndi aðeins í fasta skólanum en hinn (Sigurjón Jónsson) á fimm sveitabæjum.

Tafla 9. Nemendur, kennarar, heimili og kennslustaðir. Fjöldatölur.

\begin{tabular}{lcccccc}
\hline & \multicolumn{3}{c}{ Strandasýsla } & \multicolumn{3}{c}{ Húnavatnssýsla } \\
& $\mathbf{1 8 9 4 -}$ & $\mathbf{1 8 9 9 -}$ & $\mathbf{1 9 0 4 -}$ & $\mathbf{1 8 9 4 -}$ & $\mathbf{1 8 9 9 -}$ & $\mathbf{1 9 0 4 -}$ \\
& $\mathbf{1 8 9 5}$ & $\mathbf{1 9 0 0}$ & $\mathbf{1 9 0 5}$ & $\mathbf{1 8 9 5}$ & $\mathbf{1 9 0 0}$ & $\mathbf{1 9 0 5}$ \\
\hline Nemendur alls & 86 & 51 & 67 & 256 & 178 & 308 \\
\multicolumn{1}{c}{ a) Stúlkur } & - & 24 & 36 & 115 & 89 & 150 \\
b) Piltar & - & 27 & 31 & 141 & 89 & 158 \\
Heimili nemenda & - & 26 & - & 104 & 70 & 108 \\
Kennslustaðir & 12 & 6 & 11 & 58 & 41 & 67 \\
Meðalfjöldi nemenda á kennslustað & 7,2 & 8,5 & 6,1 & 4,4 & 4,3 & 4,6 \\
Kennarar & 4 & 2 & 4 & 13 & 10 & 16 \\
Meðalfjöldi nemenda á kennara & 21,5 & 25,5 & 16,8 & 19,7 & 17,8 & 19,3 \\
Meðalfjöldi kennslustaða á kennara & 3,0 & 3,0 & 2,8 & 4,5 & 4,1 & 4,2 \\
\hline
\end{tabular}

Lítill munur er á fjölda pilta og stúlkna pótt drengirnir séu aðeins fleiri (52\%) pau ár sem fullnægjandi upplýsingar eru um.

Engin einhlít skýring er á niðursveiflunni sem varða á skólasókn um 1900 en miklar sveiflur voru víðar. Nefna má að á árunum 1893-1905 voru nemendur í Mýrasýslu fæstir veturinn 1896-1897, 56 talsins, en flestir 1901-1902, 113 (Snorri Dorsteinsson, 2009, bls. 42). Mögulegt er að árferði hafi haft eitthvað að segja og í árferðisannál sést að hafís kom að landinu flest ár í kringum aldamótin, sýnu mestur með tilheyrandi kuldum fyrri hluta árs 1902 (Dorvaldur Thoroddsen, 1916, bls. 423-427).

Meðalfjöldi nemenda á hvern kennara var í jafnvægi í Húnavatnssýslu pessa vetur. Meðalfjöldi nemenda á kennslustað í farskólum landsins var 5,5 veturinn 1903-1904 (Guðmundur Finnbogason, 1905, bls. 40). Strandasýsla var vel yfir en Húnavatnssýsla talsvert undir. Skólaskýrslur benda til pess að heimiliskennsla hafi verið almenna reglan, sbr. dæmin hér að framan, og í skýrslu Guðmundar Finnbogasonar er nærfellt auður dálkur par sem tilgreina á lengstu vegalengd sem nemendur ganga í skóla. Í Húnavatnssýslu er nefnd hálftíma leið í Dverárhreppi, spurningarmerki er við Dorkelshólshrepp en annars staðar eyða. Engar upplýsingar bárust um petta úr Strandasýslu. Af bók Snorra Porsteinssonar má ráða að framkvæmd kennslunnar hafi verið breytileg eftir hreppum í Mýrasýslu (2009, bls. 50-52) en annars skortir rannsóknir á pessu atriði.

Áhugavert er að skoða hlutfall heimila sem áttu nemendur í skóla miðað við fjölda heimila í manntalinu 1901 (Guðmundur Jónsson og Magnús S. Magnússon, 1997, bls. 138). Í Strandasýslu eru einu samanburðartölurnar frá 1899-1900 og pá var betta hlutfall 10\% en sama ár var pað 12\% í Húnavatnssýslu. Dar hækkaði hlutfallið í 19\% veturinn 1903-1904 (Guðmundur Finnbogason, 1905, bls. 14) en lækkaði í 18\% fræðsluárið næsta. Til samanburðar var petta hlutfall 26\% á landinu öllu 1903-1904. Mikill munur var á milli héraða. Sem dæmi má nefna að hlutfallið var 30\% í Borgarfjarðarsýslu, 19\% í bæði Dalasýslu og Barðastrandarsýslu, 24\% í Skagafjarðarsýslu 
og 31\% í Eyjafjarðarsýslu að Akureyri undanskilinni. Sýslurnar við Húnaflóa voru pannig í lægri kantinum sé gengið út frá pví að hlutfall barna á sveitaheimilum hafi verið nokkurn veginn sambærilegt um land allt. Ástæður eru ugglaust margar en líklega hafa íhaldssöm viðhorf til menntunar barna í föstum skólum verið útbreiddust par sem dreifbýlið var mest. Dað er ekki til skoðunar hér en reipdrættinum á milli heimafræðslusinna og skólafræðslusinna hefur víða verið lýst (sjá t.d. Guðmundur Finnbogason, 1947, bls. 106-108 og 114-115; Loftur Guttormsson, 2008d, bls. 80-83).

\section{Aðstæður til kennslu}

Upplýsingar um aðstæður til kennslu eru fáséðar í innsendum gögnum kennara og sóknarpresta og allsendis ónógar til pess að fá heildarmynd. Elsti vitnisburðurinn er í skýrslu séra Arnórs í Tröllatungu, dags. 21. mars 1888, par sem segir að ekki hafi verið umgangskennari í Fellshreppi um veturinn en pó hafi „nokkrir unglingar notið slíkrar kennslu, sem umgangskennarar veita, á pann hátt, að foreldrar eða húsbændur barnanna hafa keypt kennslu fyrir pau hjá búsettum mönnum í hreppnum, og hafa ungmennin gengið í tíma til peirra“. Í fylgibréfi útskýrir hann aðstæður í hreppnum: „Deir, sem hafa notað pessa kennslu eru flestir mjög fátækir, og parfnast pví mjög styrks til að bera pann kostnað, sem leitt hefur af pví að veita ungmennunum pá fræðslu, sem ég álít embættisskyldu mína að krefjast, að peim sé veitt, og sem ég pví hefi gengið stranglega eftir“" (bÍ. Lh. N.J. 1888-1892. Ár 1888).

Orð séra Arnórs veita innsýn í veruleika fátæks sveitafólks. Dað átti að uppfræða börn sín í tilteknum námsgreinum en sum heimili gátu pað ekki og fengu aðstoð frá betur kunnandi nágrönnum. Annar vitnisburður um fátækt er í umsögn séra Páls Ólafssonar á Prestsbakka, dags. 7. júní 1900, um kennsluna veturinn á undan: „Dennan vetur hefur kennsla Sigurjóns [Jónssonar] eingöngu verið bundin við fátækustu heimili, sem ekki höfðu rád á að halda kennara yfir lengri tíma“" (DÍ. Lh. Nr. XII. Ár 1894-1905). Í Húnavatnssýslu er Eggert Helgason sá sem oftast minnist á fátækt. Um kennsluna 1898-1899 segir hann: „Að hvergi voru að tekin börn par sem ég dvaldi í vetur, stafaði eingöngu af fátækt heimilanna ... og af rúmleysi á heimilinu“ (DÍ. Lh. Nr. XIII. Ár 1894-1905). Vorið 1902 skrifar Eggert:

Að kennslutíminn ekki varð lengri í petta sinn en skýrslan sýnir, orsakaðist af hinum almenna bjargræðisskorti, sem pótti vofa yfir pegar á veturinn leið, sakir vanbirgða allra nærliggjandi verslana; varð ég pví frá að hverfa á tveim stöðum, er ég hafði verið ráðinn til dvalar eftir páskana. ... Ég get vel búist við, að sumir álíti pessa kennsluviðburði mína lítilsverða, par sem ég eigi er að jafnaði lengur en 2-4 vikur í senn á hverjum stað, en mér finnst, bæði, að margir fátækir barnamenn, kynoki sér við að taka kennara lengi í einu, og eins hitt, að börnin, sem haldið er að náminu, svo að segja hvíldarlaust, fari úr pví að preytast (DÍ. Lh. Nr. XIV.Ár 1894-1905).

Eggert kenndi pennan vetur sem marga aðra ,án borgana frá hlutaðeigendum“.

Lítið er vitað um húsnæðið sem notað var og alger undantekning að kennt væri í sérstöku skólahúsi. Dó segir séra Eggert Ó. Brím á Höskuldsstöđum eftirfarandi í bréfi, dags. 27. janúar 1888, um Magnús Sigurðsson (1857-1894) barnakennara í Spákonufellssókn:

Hann hefir haldið nokkurs konar barnaskóla í pinghúsi hreppsins og einkum veitt tilsögn börnum kaupmannanna O.P.Chr. Möllers og F.H. Berndsens, en par að auki haft til kennslu mörg önnur börn úr hverfinu í kring, par með ýmis börn purfalinga sveitarinnar, er ella myndi eigi hafa átt kost tilhlýðilegrar uppfræðslu, og er mér kunnugt um, að hann hefir eigi krafist sérstakrar póknunar par fyrir (DÍ. Lh. N.J. 1888-1892. Ár 1888).

Dinghúsið hét Berg eða Stóra-Berg og var reist 1880. Mögulega var pað notað til skólahalds fyrstu árin og e.t.v. í stöku tilvikum fram um aldamót en heimildir staðfesta pað ekki. Húsið var hins 
vegar örugglega notað til kennslu í fáein ár eftir gildistöku fræðslulaganna 1907 (Bjarni Guðmarsson, 1989, bls. 147-149; Sveitarfélagið Skagaströnd, 2009-2013).

Önnur frásögn um kennslu í sérstöku skólahúsi er í skýrslu séra Bjarna Pálssonar í Steinnesi, dags. 30. júlí 1904, um kennslu Dorotheu Kristínar Daníelsdóttur (1882-1963) í Sveinsstaðahreppi næstliðinn vetur: „Kristín Daníelsdóttir (kennari í Steinnesi) hafði kennsluaðferð, sem tíðkast í skólum, enda hafði hún hús, er næstum eingöngu var notað sem kennslustofa, og hafði líka sjálf fengið menntun sína á skóla“ (DÍ. Lh. Nr. II. 1903-1904). Á pessum tíma var torfbær í Steinnesi og líklega hefur Kristín fengið eitt húsanna í bænum til afnota.

Páll Friðrik Halldórsson (1875-1941) í Miðhúsum í Vatnsdal kenndi nokkra vetur. Hann lýsir kennsluaðstæðum á Blönduósi veturinn 1899-1900 í athugasemdum með skólaskýrslu, dags. 12. apríl 1900:

1. Öll kennslan fór fram í kauptúninu Blönduósi, fyrir pá sök, að heimilisfeður par kváðust purfa kennarans með, allan pann tíma, sem hann gat búist við að sinna kennslustörfum, enda áleit hreppsnefndin, að pað myndi ekki verða látið varða styrksynjun, par sem kauptúnið á engan barnaskóla og nýtur ekki neinna kaupstaðarréttinda í pví falli, og einkum, par sem kennarinn tók ekkert kaup hjá kennslupiggjendum.

2. Heimilisfeðrum peim, er kennsluna págu, kom, að áđur fengnu sampykki kennarans, saman um pað, að taka svo mörg börn frá öðrum heimilum í kauptúninu, auk sinna eigin barna til uppfræðslu, sem kennarinn treysti sér til að geta stundað kennslu á, til pess, að sem flest börn og unglingar gæetu notið kennslunnar, og var pví ákveðið

- Að skipta öllum börnunum í tvær deildir, og skyldi önnur deildin njóta kennslunnar fyrri hluta dags, en hin síðari hluta dagsins. Kennslutíminn í hvorri væri pví 5⿳1⁄2 stund á dag að meðaltali í hverri viku, hinum hluta dagsins vörðu börnin til undirbúnings undir kennslustundirnar og til leika.

- Að láta öll börnin fylgja kennaranum eftir á peim prem heimilum, sem hann kenndi á, að svo miklu leyti, sem húsrúm og aðrar kringumstæður leyfðu, en með pví að Kristján veitingamaður Halldórsson hafði langmest og haganlegast húsrúm, pá varð niðurstaðan sú, að kennslan fór fram á heimili hans, lengri tíma en pann, sem hann hélt kennarann sjálfur, pannig að hann léði skólastofu annan helming dagsins fyrir hin að teknu börn og sín eigin, pær vikur, sem kennarinn kenndi börnum hinna kennslupiggjenda heima hjá peim sjálfum, hinn hluta dags.

Daglegur vinnutími kennarans voru pví að meðaltali 11 stundir, meirihlutann af peim vikum 21 sem kennslan stóð.... Pess skal aðeins getið að ekkert barnanna var lengur en 51⁄2-6 st. við nám í skólanum á dag (DÍ. Lh. Nr. XIV.Ár 1894-1905).

Nemendur Páls voru tuttugu, 5-25 ára, frá átta heimilum. Stærsti systkinahópurinn voru öll sex börn Kristjáns veitingamanns og Sigríðar Sigurðardóttur. Kennt var heima hjá peim í tólf vikur, fimm vikur á heimili Sigríðar Möller og Björns Gunnlaugssonar Blöndal læknis og fjórar á heimili Benedikts Péturssonar smiðs. Prjú börn læknishjónanna voru í skólanum 18-21 viku, börn Kristjáns og Sigríðar í fimmtán vikur en önnur helmingi skemur eða minna. Styst var skólaganga sjö ára stúlku, tvær vikur.

Skýrsla Páls Halldórssonar veitir góðar upplýsingar um aðstæður í porpi sem var að byggjast. Íbúar á Blönduósi voru rúmlega hundrað um 1900 en í Torfalækjarhreppi öllum voru 322 heimilisfastir í árslok 1901 (Guðmundur Jónsson og Magnús S. Magnússon, 1997, bls. 79 og 93). Engin 
önnur skólaskýrsla barst úr hreppnum petta ár og augljóst að meirihluti ungmenna fékk ekki formlega skólafræðslu pennan vetur. Баð á bæði við um sveitabörnin og nokkur sem áttu heima á Blönduósi.

\section{Kennsluaðferðir}

Kennararnir eru alla jafna fáorðir um kennsluaðferðir. Langlíklegast er að utanbókarlærdómur, frásagnir kennara og yfirheyrsla hafi verið ráðandi eins og í föstum skólum (Guðmundur Finnbogason, 1905, bls. 46, 51-57; Loftur Guttormsson, 2008c, bls. 62-65). Meðmæli sóknarpresta með umsóknum kennara um styrki eru alltaf jákvæð pótt greina megi áherslumun eftir pví hver skrifar og e.t.v. að einhverju leyti um hvern var skrifað. Skoðum fáein dæmi sem varpa svolítilli skímu á verklagio.

Frímann Guðmundsson (1828-1904) á Kjalarlandi í Hallárdal nefnir í febrúar 1888 pær námsgreinar sem hann hefur kennt og bætir við: „Auk pess hef ég eftir pví sem kraftar mínir hafa leyft, leitast við að glæða menntun og upplýsingu hjá yngri og eldri með pví á tómstundum mínum að skýra frá ýmsu pví, er ég áleit fróðleik á að vita.“ Erindi hans fylgja meðmælabréf tveggja presta. Séra Eggert á Höskuldsstöðum nefnir að Frímann hafi með „siðferði sínu ... haft mjög góð áhrif á ungdóminn á heimilum peim, er hann hefur dvalið á lengra tíma“ og séra Bjarni í Steinnesi áréttar hið sama (DÍ. Lh. N.J. 1888-1892. Ár 1888).

Magnús Stefánsson (1870-1940) á Flögu í Vatnsdal ræðir skort á leiðbeiningum um kennslustarfið í skólaskýrslu 28. maí 1895:

Athugasemdir um kennsluaðferð, yfirferð nemendanna ... er naumast hægt að gjöra, par vér barnakennarar höfum í pví efni alls ekkert við að styðjast, nema pað, sem hver einn álítur best og heppilegast eftir kringumstæðunum [og] skyldan býður honum. Allir kennarar, sem annt er um starfa sinn, mundu pakksamlega taka öllum góðum leiðbeiningum yfirvaldanna um kennsluaðferðir, kennslutíma, yfirferð og annað er að unglingakennslu lýtur. Pannig lagaðar almennar leiðbeiningar mundu koma mjög miklu góðu til leiðar (DÍ. Lh. Nr. XIII.Ár 1894-1905).

Páll Friðrik Halldórsson kenndi helmingi nemenda sinna söng veturinn 1894-1895 í Vesturhópshóla- og Dingeyrasóknum og segir pá kennslu aðeins hafa farið fram á sunnudögum (bí. Lh. Nr. XIII. Ár 1894-1905). Páll hafði pví fasta viðveru á kennslustað en fór ekki heim til sín á helgidögum.

Halldór Sigurður Halldórsson segir í má 1898: „Viðræður og upplýsandi frásagnir úr ritningunni og öðrum fræðigreinum sem börnunum voru kenndar, er regla mín að iðka, nemendunum til hvíldar við námið og hugsunarhætti peirra til leiðbeiningar. - Að engu barni herði ég meira við námið en svo, að ég fái pað til að stunda nám sitt með áhuga“ (BÍ. Lh. Nr. XIII. Ár 1894-1905).

Séra Hjörleifur Einarsson á Undirfelli var viðstaddur próf að lokinni kennslu Steinunnar Bjarnadóttur (f. 1869, fór til Vesturheims 1900) vorið 1898. Í umsögn segir að hann „hafi sjaldan séð betri árangur af sveitakennslu, par auðséð var af framförum barnanna að kennari hafði framúrskarandi hæfilegleika til að kenna og lag á að hæna börnin að sér, eins og hún er alpekkt orðin fyrir í pessu byggðarlagi““ (DÍ. Lh. Nr. XIII. Ár 1894-1905).

Benedikt Frímann Magnússon (1873-1955) kenndi um árabil í Langadal og víðar. Hann gerir mismunandi proska barnanna ítrekað аð umtalsefni og segir að sömu aðferðir og skipulag geti ekki gilt fyrir alla. Hann segist vorið 1904 verja tveimur klukkutímum ,á degi hverjum, til viðtals við nemendurna, um pað, er ég áleit að best mundi skerpa og proska skilning peirra. Líka til 
að syngja alkunn og fögur íslensk pjóðlög. Í frístundum fylgdi ég peim til leika." Samtalstímarnir og önnur samvera Benedikts með nemendum voru utan stundaskrár. Árið eftir segir hann að yngri börnin hafi aðeins lært hugarreikning og pá tóku samtalstímarnir eina klukkustund á dag og söngur íslenskra ættjarðarkvæða annan til (DÍ. Lh. Nr. XIV. Ár 1894-1905).

Pessi dæmi sýna hvernig sumir kennarar vörðu hluta pess tíma sem ekki fór til beinnar kennslu. Раð hefur örugglega verið misjafnt en Jakob Frímannsson (1878-1912) á Skúfi í Norðurárdal segist hafa æft nemendur annað hvert kvöld „,í að láta hugsun sína í ljósi munnlega og hélt í peim tilgangi málfund frá kl. 9-101/2. ... Fundarstjórn og fundarritun fram fór af nemendunum sjálfum“ (DÍ. Lh. Nr. XIV. Ár 1894-1905). Um Jakob og kennslu hans segir Magnús Björnsson á Syðra-Hóli að hann hafi verið ,góður kennari, kröfuharður nokkuð, en skemmtilegur og góður nemöndum sínum.“ Jakob kenndi í Hallárdal og ,gekk á milli um helgar yfir fjöllin“ (Magnús Björnsson, 1957b, bls. 138). Hann kenndi hins vegar ekki heima á Skúfi nema einum, Páli Kolka, sem síðar varð héraðslæknir. Öðrum neitaði hann, ,sagði eins og satt var, að heima hjá sér væri aðstæður til kennslu svo erfiðar að ekki væri viðhlítandi. Húsakynni pröng og hrörleg og tilsögnina varð að veita í baðstofu og hafa í ígripum frá gegningum og öðrum bústörfum“ (bls. 140). - Jakob á Skúfi var sonur fyrrnefnds Frímanns Guðmundssonar en um hann hefur Magnús á Syðra-Hóli einnig skrifað (Magnús Björnsson, 1957a) og lýst kennsluaðferðum hans. Bróðir Jakobs var Frímann Frímannsson (1872-1920) sem líka fékkst við sveitakennslu skamma hríð.

Guðmundur Finnbogason telur að skilyrði góðrar kennslu séu prjú: „góðir kennarar, góðar kenslubækur og góð kensluáhöld. En öllu pessu er víða mjög ábótavant hjá oss“ (Guðmundur Finnbogason, 1905, bls. 52). Hann segir einnig að hvorki séu viðunandi hjálpargögn til staðar né kennslubækur (bls. 51-52). Undir pað má taka pví í skólaskýrslunum eru drjúgar upplýsingar um námsefnið, væri pað til á annað borð, og fáeinir vitnisburðir eru um hjálpargögn, einkum kort til landafræðikennslu. Dví efni verða ekki gerð skil hér en bent skal á skrá Guðmundar Finnbogasonar um bækur sem notaðar voru veturinn 1903-1904 (bls. 36) og tvo yfirlitskafla Ólafs Rastrick í Almenningsfređslu á Íslandi, sem pó taka aðeins að litlum hluta til námsefnisframboðs fyrir 1907 (Ólafur Rastrick, 2008a og 2008b).

Áhugasömum um hvaða námsefni var notað við Húnaflóa á pessum árum má til dæmis benda á ítarlega bókalista og kennslugagnaskrár Sigurgeirs Ásgeirssonar 1896 og áfram (DÍ. Lh. Nr. XII. Ár 1894-1905) og Guðmundar Davíðssonar (1873-1953), kennara í Vatnsdal, vorið 1902 (DÍ. Lh. Nr. XIV. Ár 1894-1905). Í nokkrum skýrslum leggja kennarar mat á námsefnið og eru umsagnir peirra oftast neikvæðar.

\section{Námsgreinar}

Skyldunámsgreinar voru fjórar; kristinfræði, lestur, skrift og reikningur. Kristinfræðinni var skipt í kverfræðslu og biblíusögur og var hið fyrrnefnda aðallega fermingarundirbúningur. Um pessar greinar og sögulegar forsendur er fjallað í Almenningsfreðslu á Íslandi og ástæðulaust að endurtaka pað hér (Loftur Guttormsson, 2008a, bls. 21-35 og 2008b, bls. 45-49).

Fljótlega bættust við landafræði og náttúrufræði og frá 1889 urðu barnaskólar í péttbýli að kenna pær greinar ef peir sóttu um landssjóđsstyrk. Einnig var farið að kenna sögu í sömu skólum og með fræðslulögunum 1907 urðu pessar prjár hluti af skyldunámi barna (Ólafur Rastrick, 2008c, bls. 196). Вað var pví eðlilegt að kennsla í peim næði smám saman út í sveitirnar. Guðmundur Finnbogason birtir yfirlitstöflu um hversu mörg börn og unglingar fengu kennslu í hverri námsgrein (Guðmundur Finnbogason, 1905, bls. 14-15) og pví er hægur vandi að bera héruðin við Húnaflóa saman við landið allt, sjá Töflu 10. Kaupstaðarskólunum í Reykjavík, á Ísafirði, Akureyri og Seyðisfirði er sleppt til pess að gera samanburðinn sem raunhæfastan. 
Tafla 10. Pátttaka nemenda eftir námsgreinum. Hlutfallstölur.

\begin{tabular}{|c|c|c|c|c|c|}
\hline \multirow[b]{2}{*}{ Námsgreinar } & \multirow[b]{2}{*}{ Skýrsla GF 1903-1904 } & \multicolumn{2}{|c|}{ Strandasýsla } & \multicolumn{2}{|c|}{ Húnavatnssýsla } \\
\hline & & $\begin{array}{c}1894- \\
1895\end{array}$ & $\begin{array}{c}1904- \\
1905\end{array}$ & $\begin{array}{c}1894- \\
1895\end{array}$ & $\begin{array}{c}1904- \\
1905\end{array}$ \\
\hline Lestur & $88 \%$ & $63 \%$ & $78 \%$ & $63 \%$ & $74 \%$ \\
\hline Kver & $59 \%$ & $28 \%$ & $41 \%$ & $51 \%$ & $45 \%$ \\
\hline Biblíusögur & $64 \%$ & $21 \%$ & $36 \%$ & $51 \%$ & $53 \%$ \\
\hline Skrift & $90 \%$ & $90 \%$ & $80 \%$ & $86 \%$ & $87 \%$ \\
\hline Réttritun & $59 \%$ & $64 \%$ & $85 \%$ & $72 \%$ & $62 \%$ \\
\hline Reikningur & $89 \%$ & $79 \%$ & $94 \%$ & $81 \%$ & $86 \%$ \\
\hline Náttúrufrææi & $20 \%$ & $4 \%$ & $31 \%$ & & $15 \%$ \\
\hline Landafræði & $30 \%$ & $19 \%$ & $53 \%$ & $13 \%$ & $21 \%$ \\
\hline Saga & $6 \%$ & & $3 \%$ & $5 \%$ & $7 \%$ \\
\hline Danska & $13 \%$ & $8 \%$ & $14 \%$ & $16 \%$ & $15 \%$ \\
\hline Söngur & $8 \%$ & & & $3 \%$ & $4 \%$ \\
\hline Íslenska & & & $8 \%$ & $3 \%$ & $4 \%$ \\
\hline Málfrææði & & & & $1 \%$ & $1 \%$ \\
\hline Enska & & & & $2 \%$ & $1 \%$ \\
\hline Handavinna & & & & & $2 \%$ \\
\hline Eðlisfrææð & & & & $0,4 \%$ & \\
\hline Nemendur alls & 5277 & 86 & 78 & 256 & 308 \\
\hline
\end{tabular}

Á peim áratug sem taflan tekur til fjölgaði nemendum hlutfallslega í meirihluta námsgreina í báđum sýslum. Í Strandasýslu parf að taka tillit til pess að eldri deildin á Heydalsá er með í tölunum 1904-1905 og pað munar um pá ellefu sem par voru. Engir peirra fengu tilsögn í lestri, kristinfræði eða skrift en peir sátu hins vegar flestir eða allir tíma í réttritun, reikningi, landafræði og náttúrufræði. Deir sex nemendur sem sátu íslenskutíma voru allir í pessari deild.

Breytingar í Húnavatnssýslu parfnast ekki sérstakra skýringa. Eftirtektarverðast er að náttúrufræði kemst vel á blað og landafræðikennsla sömuleiðis.

Húnaflóasvæðið var nokkuð undir landsmeðaltali í lestri og kristinfræði fræðsluárið 1904-1905 og lítillega í skrift. Aðrar greinar eru vart samanburðarhæfar hvað Strandasýslu varðar vegna Heydalsárskólans en Húnavatnssýsla er vel undir meðaltali í náttúrufræði og landafræði.

Dessi munur á rót í pví að fastir skólar voru almennt með meiri pátttöku í einstökum námsgreinum en farskólar og heimilisfræðsla, starfstími peirra var lengri og í peim voru kenndar fleiri greinar (Bragi Guðmundsson, 2005, bls. 111-113; Guðmundur Finnbogason, 1905, bls. 44-46).

Engar upplýsingar eru um fjölda fastra skólahúsa á pessum árum aðrar en úttekt Guðmundar Finnbogasonar (1905, bls. 18-29) sem nefnir 47. Sum voru byggð sem skólahús eingöngu en flest gegndu ýmsum öðrum hlutverkum. Ef frá eru dregin skólahús í kaupstöðunum fjórum eru eftir 42 sem Guðmundur kallar barnaskólahús.

Hagstofa Íslands skráir 34 péttbýlisstaði auk kaupstaðanna fjögurra árið 1901 (Guðmundur Jónsson og Magnús S. Magnússon, 1997, bls. 120-122) og pegar peir eru bornir saman við úttekt Guðmundar sést að skólahús voru í tuttugu peirra. Eftir stendur að 22 skólahús voru í dreifbýli, eitt peirra á Heydalsá en ekkert í Húnavatnssýslu. 


\section{Samantekt}

Í inngangi eru skilgreind sex meginviðfangsefni og hér verða helstu niðurstöður reifaðar.

Aldursdreifing ungmenna í Strandasýslu og Húnavatnssýslu um aldamótin 1900 var nánast hin sama og á landinu öllu. Hlutfall barna sem fengu fræðslu hjá sveitakennurum fór smám saman hækkandi á tímabilinu sem skoðað er. Prátt fyrir pað voru sýslurnar tvær vel undir landsmeðaltali pegar kom að hlutfallslegri skólasókn sé gengið út frá pví að hlutfall barna á sveitaheimilum hafi verið sambærilegt um land allt.

Greinilegur landfræðilegur munur var á milli sveitarfélaga í Strandasýslu. Minnst var formleg barnafræðsla í sveitarfélögunum norðan Steingrímsfjarðar en meiri eftir pví sem sunnar dró. Í Húnavatnssýslu var mjög lítið um formlega fræðslu við Hrútafjörð og norðan Hallár á Skaga. Allmikill munur var á milli annarra svæða innan héraðs.

Börn húsbænda, fósturbörn og tökubörn mynduðu kjarnann í nemendahópnum, voru 85-89\% pá vetur sem skoðaðir voru. Eftirtektarvert er samt að börn og systkini húsbænda voru aðeins 71\% heildarinnar 1894-1895 en fjölgaði í 78\% áratug síðar. Niðursetningum fækkaði mikið á tímabilinu og í heild fækkaði nemendum án sýnilegra beinna tengsla við húsbændur úr 15\% 1 10\%. Hlutfall pilta og stúlkna var tiltölulega jafnt, piltarnir pó ívið fleiri eða 52\%.

Degar heimilisfesti nemenda er borin saman við kennslustaðina er niðurstaðan sú að heimiliskennsla var ríkjandi fræðsluform við Húnaflóa allt tímabilið 1887-1905 og tiltölulega fá börn gengu til kennslu á milli bæja. Nemendahópar voru að jafnaði fámennir og aldursbil breitt. Kennslustaðir voru 70 veturinn 1894-1895 og 78 áratug síðar. Um efnahag peirra heimila sem hýstu heimiliskennara er lítið vitað en nokkrir vitnisburðir eru um hvernig komið var til móts við börn fátækra foreldra. Áhugaverð er lýsing á kennsluaðstæðum á Blönduósi um 1900. Einum námshópi var kennt fyrir hádegi en öđrum eftir. Dess háttar tvísetning tíðkaðist víða alla tuttugustu öld.

Litlar upplýsingar eru um húsakynni eða aðrar ytri aðstæður. Ekkert fast skólahús var við Húnaflóa par til heimavistarskólinn á Heydalsá tók til starfa 1897 og ekkert slíkt reis næsta áratuginn.

Fátt er vitað um kennsluaðferðir og reikna má með að flestir sveitakennarar hafi byggt á eigin reynslu, hvort heldur var úr skóla eða sjálfsnámi. Sumir lýsa utanbókarlærdómi og yfirheyrslum en einnig voru nemendur æfðir í að skrifa eftir upplestri. Fáeinir kennarar nefna hvernig peir nýta stundir utan kennslutímans, í útivist og á kvöldin.

Námsgreinar voru að jafnaði færri par sem heimiliskennsla og farkennsla voru ríkjandi form en í föstum skólum. Húnaflóasvæðið var par engin undantekning og má rekja ástæðurnar til skamms námstíma hvers nemanda og trúlega einnig slaks undirbúnings margra kennara og skorts á kennslugögnum.

Degar allt er tekið saman og aðstæður nemenda og kennara í Strandasýslu og Húnavatnssýslu bornar saman við önnur héruð og landssvæði má fullyrða að byggðirnar við Húnaflóa hafi að ýmsu leyti staðið höllum fæeti hvað varðaði próun uppfræðslu og skólamála. Par réðu líklega mestu dreifð búseta, erfiðar samgöngur og skortur á péttbýli en einnig mögulega efnalegar aðstæður og íhaldssöm viðhorf til skólagöngu.

Margar eyður eru ófylltar í skólasögu Íslendinga og drjúgar heimildir liggja lítt eða ekki hreyfðar í skjalaöskjum stofnana eða utan peirra. Hvað barnafræðsluna varðar er áberandi mikil vöntun á rannsóknum á dreifbýlum svæðum pótt vissulega hafi verið skrifaðar prófritgerðir um einstök sveitarfélög. Dær rannsóknir ná yfirleitt til afmarkaðra tímabila eftir 1907, enda eru prentaðar fræðsluskýrslur aðgengilegur og mikilvægur brunnur að sækja í pegar pangað er komið. Minna er um notkun óútgefinna skjala og annarra vitnisburða. Mikilvægt og fjölbreytt efni er pví vannýtt og pað parf að virkja til enn frekari rannsókna. 


\section{On rural teaching in the districts of Strandasýsla and Húnavatnssýsla 1887- 1905}

From shortly before the middle of the 18th century, Icelandic homes were obliged to provide children with instruction in religion and reading. This obligation was extended in 1880, when writing and arithmetic were added. The homes were supposed to provide the instruction, monitored by parish priests. By the middle of the 19th century, the need for schools for children and teenagers was generally recognized and they were founded one by one, primarily in urban areas. In the countryside, teaching mainly took place in homes and clergymen were supposed to monitor the children's progress.

Many were concerned about the lack of schools but proponents of improved education often had to tackle obstacles deeply rooted in Icelandic history and culture, as well as in the firm belief that home schooling was a cornerstone of society. There were also economic hindrances due to the high level of poverty amongst the general population and an ingrained reluctance to use public funds to cover communal expenses.

This article is based on data regarding rural teaching in two districts in the Húnaflói Bay area; that is, Strandasýsla and Húnavatnssýsla, prior to the formal introduction of compulsory education in 1907. The National Archives of Iceland hold reports from 1887 and onwards that deal with grant applications from rural teachers. The aim is to shed some light on the students who received this teaching and their circumstances.

The main conclusions are the following:

- The age distribution of children and teenagers in the Húnaflói Bay area around the turn of the 20th century was more or less the same as elsewhere in the country. The proportion of children who were taught by rural teachers gradually grew; nevertheless the two districts were well below the national average as regards the proportional school attendance of Icelandic youth.

- There was a clear difference between the municipalities in Strandasýsla as regards the level of children's formal education. It was lowest north of Steingrímsfjörður but increased in the southern parts. In Húnavatnssýsla, very little formal education was available in Hrútafjörður and the northern part of the Vindhælishreppur municipality, while much more was on offer elsewhere.

- An analysis of pupils' social standing reveals that, in the winters examined, the majority (85-89\%) of the group of pupils was made up of children of farm owners, foster children and adopted children. The number of paupers decreased sharply over the period and the proportion of pupils who had no direct connection to farm owners went from $15 \%$ to $10 \%$. The distribution between boys and girls was relatively even, even though the boys were slightly more numerous, or $52 \%$.

- Home schooling was the main form of education throughout the period and relatively few children received their teaching away from their home farm. All in all, there were 70 places of teaching in the winter of 1894-1895 and 78 a decade later. It has sometimes been assumed that teaching mainly took place in the homes of well-off farmers, but this was by no means always the case. Sources contain a few examples of how children of poor parents were attended to. 
- There was no designated school building in the Húnaflói Bay area until the boarding school at Heydalsá started its operations in 1897, and no other building of that kind was built in the next decade. As a result, home schooling was the dominant form of education and the pupil groups were small. Consequently it was relatively easy for the teacher to attend to each and every student and the age range was often quite broad.

- Little is known about teaching methods and it can be assumed that most rural teachers based these on their own experience, gained either from school or their self-education. Some of them describe rote learning and questioning but there are other examples of students being trained in dictation.

- In general, fewer subjects were taught where home schooling was predominant than in set schools. Here, the Húnaflói Bay area was no exception. The main reason for this was the short period of study available to each student, and probably also the limited preparation of many teachers and lack of teaching materials.

- When the conditions of pupils and teachers in Strandasýsla and Húnavatnssýsla are summed up and compared to those in other parts of the country it seems safe to say that the Húnaflói Bay area was in many ways disadvantaged with regard to the development of education and schools. This can probably mainly be traced to a sparse population and absence of urban areas, although economic reasons and conservative views on education are also likely to have played their part.

Key words: Rural teaching, home schooling, itinerant school, District of Strandasýsla, District of Húnavatnssýsla

\section{Um höfund}

Bragi Guðmundsson (bragi@unak.is) er prófessor í sagnfræði við Hug- og félagsvísindasvið Háskólans á Akureyri. Hann er með cand. mag.-próf í sagnfræði frá Háskóla Íslands og nám til kennsluréttinda frá sama skóla. Hann er með leyfisbréf sem framhaldsskólakennari og prettán ára starfsreynslu sem slíkur. Bragi hefur unnið að ytra mati á rúmlega tuttugu íslenskum framhaldsskólum. Rannsóknir hans á seinni árum hafa aðallega beinst að notkun grenndaraðferðar við kennslu og íslenskri skólasögu.

\section{About the author}

BragiGuðmundsson (bragi@unak.is) is professor of history at the School of Humanities and Social Sciences at the University of Akureyri. He holds a cand. mag. degree in history and a postgraduate diploma in teaching from the University of Iceland. He is a licensed upper secondary school teacher and worked in that field for thirteen years. Bragi has been an external examiner at more than twenty Icelandic upper secondary schools. In recent years, his research has mainly focused on the use of local studies in teaching and the history of Icelandic schools. 


\section{Heimildir}

Bjarni Guðmarsson. (1989). Byggðin undir Borginni. Saga Skagastrandar og Höfðahrepps. Höfðahreppur.

Björk Ingimundardóttir. (2019). Prestaköll, sóknir og prófastsdami á Íslandi 1-2. Djóðskjalasafn Íslands.

Bragi Guðmundsson. (2005). Túngrös og pálmaskógar - Saga, landafræði og náttúrufræði. Í Trausti Porsteinsson og Bragi Guðmundsson (ritstjórar), Andans arfur. Tíu erindi um manninn, freðimanninn, menntafrömuðinn, sálfraðđinginn og bókfraðinginn Guðmund Finnbogason (bls. 101-117). Háskólinn á Akureyri.

Bragi Guðmundsson. (2020). Um sveitakennara í Strandasýslu og Húnavatnssýslu 1887-1905. Rádstefnurit Netlu - Menntakvika 2020. https://netla.hi.is/serrit/2020/menntakvika_2020/01.pdf

Guðmundur Finnbogason. (1905). Skýrsla um fraðslu barna og unglinga veturinn 1903-1904. [Án útgefanda].

Guðmundur Finnbogason. (1947). Alpingi og menntamálin. Alpingissögunefnd.

Guðmundur Jónsson og Magnús S. Magnússon (ritstjórar). (1997). Hagskinna. Sögulegar hagtölur um Ísland. Hagstofa Íslands.

Íslensk erfðagreining og Friðrik Skúlason. (1997-2020). Íslendingabók. www.islendingabok.is

Landshagsskýrslur fyrir Ísland 1903 I.

Loftur Guttormsson. (2008a). Fræðsluhefðin: Kirkjuleg heimafræðsla. Í Loftur Guttormsson (ritstjóri), Almenningsfreèsla á Íslandi 1880-2007, 1: Skólahald í ba og sveit (bls. 21-35). Háskólaútgáfan.

Loftur Guttormsson. (2008b). Pjóðfélagsbreytingar og menntamál. Í Loftur Guttormsson (ritstjóri), Almenningsfreeðsla á Íslandi 1880-2007, 1: Skólahald í ba og sveit (bls. 38-53). Háskólaútgáfan.

Loftur Guttormsson. (2008c). Sjálfsprottnir skólar. Í Loftur Guttormsson (ritstjóri), Almenningsfreðsla á Íslandi 1880-2007, 1: Skólahald í be og sveit (bls. 56-71). Háskólaútgáfan.

Loftur Guttormsson. (2008d). Tímamótin 1907. Í Loftur Guttormsson (ritstjóri), Almenningsfreeðsla á Íslandi 1880-2007, 1: Skólahald í ba og sveit (bls. 75-89). Háskólaútgáfan.

Magnús Björnsson. (1957a). Frímann barnakennari. Í Mannaferðir og fornar slóðir (bls. 103-123). Bókaforlag Odds Björnssonar.

Magnús Björnsson. (1957b). Jakob Frímannsson. Í Mannaferđir og fornar slóðir (bls. 124-146). Bókaforlag Odds Björnssonar.

Ólafur P. Kristjánsson og Sigrún Harðardóttir (ritstjórar). (1985-1988). Kennaratal á Íslandi 1-5 (2. útgáfa). Oddi.

Ólafur Rastrick. (2008a). Námsgreinar og námsefni. Í Loftur Guttormsson (ritstjóri), Almenningsfreæðsla á Íslandi 1880-2007, 1: Skólahald í bee og sveit (bls. 163-177). Háskólaútgáfan.

Ólafur Rastrick. (2008b). Hefðbundnar kjarnagreinar. Í Loftur Guttormsson (ritstjóri), Almenningsfreæðsla á Íslandi 1880-2007, 1: Skólahald i bee og sveit (bls. 180-192). Háskólaútgáfan.

Ólafur Rastrick. (2008c). Nýjar skyldunámsgreinar. Í Loftur Guttormsson (ritstjóri), Almenningsfreæðsla á Íslandi 1880-2007, 1: Skólahald í bee og sveit (bls. 196-209). Háskólaútgáfan.

Ólöf Garðarsdóttir. (2010). Barnakennarar á Íslandi um aldamótin 1900. Ráđstefnurit Netlu - Menntakvika 2010. http://hdl.handle.net/1946/7810

Snorri Dorsteinsson. (2009). Barna- og unglingafraðsla í Mýrasýslu 1880-2007. Uppheimar.

Sveitarfélagið Skagaströnd. (2009-2013). Óútgefin húsaskrá um byggð í porpinu á Skagaströnd á árunum 1840-1940.

Djóðskjalasafn Íslands. (e.d.). Manntöl. www.manntal.is

pjóðskjalasafn Íslands. (e.d.). Vefsjá kirkjubóka. www.skjalasafn.is

Dorvaldur Thoroddsen. (1916). Árferði á Íslandi í púsund ár. Hið íslenska fræðafjelag. 
Pjóðskjalasafn Íslands [PÍ]. Öskjur sem geyma gögn sem notuð eru á einn eða annan hátt, hvort sem til peirra er vitnað í tilvísunum eða ekki. Lh. er skammstöfun fyrir Landshöfðingjasafn og Stv. er skammstöfun fyrir Skjalasafn stiftsyfirvalda:

Lh. Nr. II. 1903-1904. Skýrslur um fræðslu barna og unglinga veturinn 1903-1904. Ísafjarðarprófastsdæmi - Suður-Múlaprófastsdæmi.

Lh. N.J. 1888-1892. Ár 1888. N nr. 480-559.

Lh. N.J. 1888-1892. Ár 1889. N nr. 630-699.

Lh. N.J. 1888-1892. Ár 1890. N nr. 570-589.

Lh. N.J. Ár 1891. N nr. 636-649.

Lh. N.J. Ár 1894. N nr. 730-809.

Lh. Nr. XII. Ár 1894-1905. Sveitakennarar Strandasýsla 1894-1905.

Lh. Nr. XIII. Ár 1894-1905. Sveitakennarar Húnavatnssýsla 1894-1899.

Lh. Nr. XIV. Ár 1894-1905. Sveitakennarar Húnavatnssýsla 1900-1905.

Stv. D.I. Nr. 342-345.

Sýslumaðurinn í Strandasýslu PG/3, örk 3. Einkunnabók 1897-1950.

Bragi Guðmundsson. (2021).

Um barnafræðslu í Strandasýslu og Húnavatnssýslu 1887-1905

Netla - Veftímarit um uppeldi og menntun. Menntavísindasvið Háskóla Íslands.

Sótt af http://netla.hi.is/greinar/2021/alm/11

DOI: https://doi.org/10.24270/netla.2021.11 